\title{
What Goes Up Must Come Down:
}

\section{The Combat of Impulses in Italian Futurism and Rationalism}

\author{
Ross Jenner
}

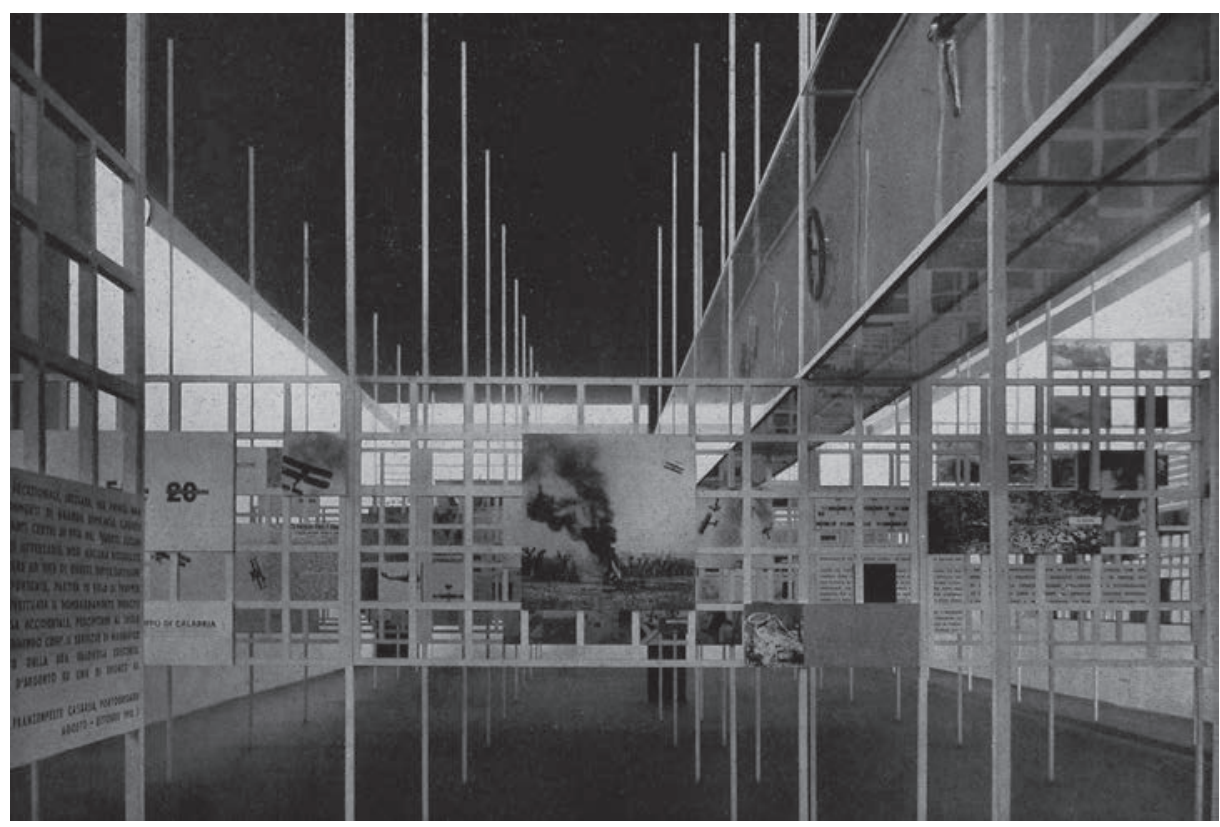

Figure I: Persico, Nizzoli and Fontana, Hall of the Gold Medals, 1934.

\section{The Impulses: Lightness and Gravity}

The conflicting impulses of lightness and gravity are more often taken for granted than theorised. They are experienced as the will to ascend from the earth or to merge with it. In modernity, the propensity to launch buildings into the air is usually taken to refer to the will to rise above and remake the world in a new mould, to break with the weight of traditional materials and contexts. So, recent critiques of modernist lightness, such as Adolf Max Vogt's concept of the 'suspension-syndrome' (1989) and John Rajchman's of 'immateriality' (1994b; 1994c) have focused on the elements of 'dematerialisation' and 'transparency'. ${ }^{1}$ Building in the air manifests a will to reject earthly and bodily matter. ${ }^{2}$ The earth shows traces, gets worn, accumulates history. The air does not; it offers least resistance to being filled with new projects. ${ }^{3}$ But Rajchman argues, referring to Nietzsche and Calvino, that the lightness of today's architecture is more a question of how to displace boundary stones, how to lighten the earth itself.
I. See also Fossati (197I) and Lynn (1994).

2. See Vogt (1989) and Rajch$\operatorname{man}(1994 a)$.

3. Research into the question of the 'spatial revolution' brought about by aviation confirms such a view. See Ingold (1978); Wohl (1994); Boatto (1992); and Asendorf (1997). 
Could something of this other lightness, which is one of 'thinking otherwise', not be found already in the rationalism of Edoardo Persico in the 1930s and of Franco Albini from the 1930s to the '50s? Moreover, there would seem to be other forms of lightness, even within modernism, where the conflicting impulses come to a temporary halt. This lightness is not simply concerned with transcendence, nor the actualisation of force and will, but rather with the suspension of these very factors. It appears in some modernist work as a figure of potentiality. In the hands of Persico and Albini, displacement into the air also indicates an instability, risk and balance which entails suspension of judgement, of self in irony, and of necessity in grace, achieving an elusive and paradoxical lightness.

\section{Weight/Will as a Field of Conflict}

That buildings must resist the force of gravity seems a constant-but is it a coincidence that the expression of gravitational force came to be theorised with the advent of a voluntarist philosophy? In Schopenhauer's account, architecture brings to clearer perception some of the ideas that are the lowest grade of the will's objectivity:

The conflict between gravity and rigidity is the sole aesthetic material of architecture ... It solves this problem by depriving these indestructible forces of the shortest path to their satisfaction, and keeps them in suspense through a circuitous path; the conflict is thus prolonged, and the inexhaustible efforts of the two forces become visible in many different ways. (Schopenhauer, 1958: 214)

Heinrich Wölfflin's Grundthema der Architektur (1994) started from a similar point but emphasized a living, upward striving side rather than the delay of gravitational forces. The effects of gravity are deduced from physical experience and always associated with a decrease in vital energy. It is the will that counter-acts this decrease and, through the "liberation from material gravity", realises and releases potential (161). Wölfflin proposed an empathy between building and body:

Matter is heavy; it presses down and wants to spread out formlessly on the ground. We know the force of gravity from our own body. What holds us upright and prevents a formless collapse? It is the opposing force that we may call will, life, or whatever. I call it force of form (Formkraft). The opposition between matter and force of form, which sets the entire organic world in motion, is the principal theme of architecture. (159)

In Italy, this will was expressed in Futurism through figures of flight and speed as the means of overcoming gravity and rising above the ruins of the past, from at least as early as its official foundation in 1909. Together with the dissolution of matter into energy, aerial figures of thought became variations on the theme of transcendence. 


\section{The Double Face of Lightness}

Filippo Tommaso Marinetti's Futurism is bent on simultaneously fleeing, rising above, and overcoming the earth. With a note of pathos echoing Nietzsche's Zarathustra, the Founding Manifesto of Futurism ends with the refrain: "Lift up your heads! ... Erect on the summit of the world, once again we hurl our defiance to the stars! ..." (1909/1968: 13). But Marinetti's eulogy of flight and speed, his frenetic activity, turns out to be a means of exorcising the anxieties of technology and warding off the abyss of nothingness. His combat with subjectivity and interiority is intimately bound up with the association of flight with escape from closure. Flight exteriorises the will and unites desire with the exterior world of machines, the sky, and the universe. Marinetti's modernity harbours a rejection of matter or, at least, an intent to transform it into a new higher, more energetic form through the 'metalisation' of the flesh, electricity, the penetration of electromagnetic waves, and dissolution into particles.

Umberto Boccioni shares with Marinetti an enthusiasm for verticality, and a voluntarism that is most stridently expressed in the concluding words of his 1914 Transcendentalismo fisico e stati d'animo plastici (1977: 145):

Have we perhaps begun to understand man's aspiration to travel at 300 kilometres an hour? Do we know why he is prepared to risk his life climbing to 5,000,10,000, 20,000 metres-to infinity? There is only one necessity, only one will: to ASCEND.

Movement and light dissolve the materiality of bodies. Matter becomes permeable without fixed surface and co-extensive with universal space. The distance between things is composed not of empty space but "continuities of matter of different intensity" (Boccioni, 1971: 42). Material is redeemed from its inertia by means of a spiritualising bath that gives precedence to the idea of transcendence before that of immanence. The process is double: matter is spiritualised, the spirit is incarnate in matter, the state of mind becomes plastic. Since, for Boccioni, objects are never completed, matter, work, action, becoming, and future are all associated. The manifesto envisages ever-increasing possibilities not only in depth-but, above all, in height. He pioneers fusion, simultaneity, and space as an all-embracing field of intensities, open, scattered, multiple, energised, aerated, and lightened. Fragments are not arbitrarily dispersed, however, but aligned to vectors of possibilities. ${ }^{4}$ In Enrico Prampolini's manifesto (1984: 88), Futurist architecture will have "an atmospheric genesis" in the "atmospheric style", creating "a unique abstract entity", "abstract consequence of energies" amalgamating "air", "light" ("natural energies") and "force" ("artificial energy").

This is one side to the freedom that lightness can offer: lightness as freedom from the weight of earthly matter. There is another side, which is not always easily distinguished: lightness as freedom within, no longer set in opposition to matter. Italo Calvino (1988) conceived of a lightness that is flighty and inexplicable; it will not let itself be constrained to fall into any definite place. ${ }^{5}$ This inexplicable lightness is capable of dissolving the opacity of the world. Unpredictable deviations and combinations of atoms and letters, graceful minutiae, infinite unexpected possibilities, the invisible, and even nothingness elude the crushing weight of matter. Recomposed,
4. "All types of lines should be used at any point in whatever means. This autonomy of the component parts of the edifice will break up the uniformity and create an architectural Impressionism, and from this new possibilities can flow." (Boccioni, 1997: 185) In the continuity and reciprocity of subject and world, object and object, environment and figure, there is a coming and going of energy, following Henry Van de Velde's energist principle of force-lines and Albert Einstein's lightening equation, mass $=$ energy. See also note 10 .

5. Calvino's first lecture in Lezioni americane has become a celebrated starting point for current discussions on lightness. Regarding its reception, see, for example, Gregotti (1988), Rajchman (1994c), and Frascari (2000). 
6. Recounted by Paul Celan in Agamben (1986: 4I)

7. The ecstatic uplift and wildly exuberant flows, the futurist impulse to an exultant ascension, to upward projection, had come already in the Futurism of Fillia's paintings and Alberto Sartoris' drawings to an end, arrested in suspension. lightness is brought back to the mobility of mental processes. Knowledge of the world then tends to break up its solidity through the play of subtle and imperceptible elements-or, at least, a high degree of abstraction. Lightness is thus a way of looking at the world from a different perspective, obliquely. It is a reminder not to sink into heaviness and inertia; not to ignore, and hence suffocate, the slightest brush of thought or feeling. Lightness engenders the flowering of a consciousness that evades the predictable and opens up to the possible.

Simultaneously, Calvino highlights the paradoxes of lightness: definitions cancel lightness out of existence, yet it can be nourished by science and philosophy as a flight of thought. And it is cancelled out of existence by attempts to grasp it: it reverses into its opposite the moment it is seized. Lightness is "the unattainable object of an endless quête"; if one says one has gained it, one has lost it (Calvino, 1996: 7). He concludes with Kafka's enigmatic story "Der Kübelreiter". In the midst of winter the narrator goes out for coal with a bucket which, along the way, he comes to ride. But it floats too high in the air to come down and get coal from the merchant. Hovering, he begs for a shovelful but the merchant's wife unties her apron and shoos him away as if he were a fly. The bucket knight and bucket fly off, blown about like a feather in the wind, to vanish beyond the Ice Mountains. The reason for the quest-and thus lightness-is a need and a lack, which their satisfaction would annul. A full bucket would cancel lightness. In attaining the object, "everything we chose and value in life for its lightness soon reveals its true unbearable weight" (7). Kafka's bucket is a reminder of another paradox: that emptiness "is just as concrete as solid bodies" (8); that the bucket's void is infinitely greater than the thin rim that encloses it. The bucket flies because it is empty, like molecules that flit around because they are only motes in a void. Fundamentally part of their opposites, lack, absence, and emptiness also signify potentiality.

Giorgio Agamben adds to Kafka's story an urgently condensed sequel of a teacher of gravity who, having "brought proof after proof to bear", to which nobody listened, "launched himself into the air and, hovering, continued to teach that law-now they believed him" without being surprised that he did not come back from the air. ${ }^{6}$ There is no better proof of gravity than flight. Agamben finds another instance of the paradoxical nature of lightness in Nietzsche's Zarathustra, where the problem of ascension and gravity is, however, symmetrically inverted. In the episode "Of the Vision and the Riddle", the prophet is mounted by the "spirit of gravity" (half dwarf, half mole), who whispers to him, "You stone of wisdom! You have thrown yourself high, but every stone that is thrown must-fall!" In the episode "Of the Spirit of Gravity", man is likened to a beast of burden: "Only man is hard to bear! That is because he bears too many foreign things upon his shoulders" and "lets himself be well laden" (Nietzsche, 1961: 211). Agamben notes that Zarathustra "accepts in substance the judgment of the dwarf ('every stone that is thrown must-fall'), but astutely flips it into its opposite: the stone that falls back again eternally is the lightest thing of all" (Agamben, 1986: 42). Burdened with the greatest weight, Zarathustra wants to turn it into the lightest wings, convert weight into the most elevated flight. Supreme lightness is at one with "the greatest weight": the eternal return of the same. 
The bucket knight, on the other hand, deprived as he is of all weight, wants instead to come down to earth to find gravity but is carried off forever. In Agamben's reading, he seems to say that "true lightness ... is not the eternal return, but never to return. So desolate, in appearance, is his lesson. We can believe him, precisely because he will never come back again to repeat it" (42). Levity and desolation often belong together. Freedom from weight brings with it a potential loss. The bucket knight's wish for freedom from want and lack sets him adrift in the act of overcoming them-into a realm of improbability, uncertainty and fantasy. Here, to be in the air is to have lost, or not yet attained, the status of actuality. This might also be said about Persico and Albini's Rationalism. Excluded from monumental works by the machinations of a powerful minority of traditionalists, they found their outlet only in the all-too-light world of small projects, exhibition design and displays.

In the architecture of the 1920s, the figures of movement and aerial pressures pioneered by Futurism had been arrested. Ascension and flight changed into the motif of hovering. The free-flowing air of Impressionism and Futurism now flipped into the opposite pole of the paradox: a space of emptiness, alienation, detachment. ${ }^{7}$ Perhaps a distinction is viable between a lightness of ascension, an initial rebellious flight away from earth, and a lightness of suspension, a levelling off in both later Futurism and in Rationalism.

\section{Suspension: Between Lightness and Gravity}

Given Italian Rationalist architecture's orientation towards transcendence, there would appear to be little hope of finding in it forms of a lightness that are understood as freedom within earthly matter. But they are indeed to be found the works of Persico and Albini with their different concepts of lightness, of 'thinking otherwise'.

\section{The Withholding of Impulses in Potentiality}

In 1934-5, Persico designed two Parker shops in Milan. ${ }^{8}$ Shortly afterwards, Raffaello Giolli commented: “... everything is reduced to purpose. But in undressing architecture thus to the point of making it only a vibration of lines, Persico went beyond that point" (1937: 30). Beyond the reduction to purpose, beyond divesting, the issue is not simply an emptying out. Nor is it just hygiene, the application of a coat of white paint as a whitening out of psycho-sexual desires, Existenz Minimum, essentialism. Nor is it 'less is more', whose silence negatively states the limits of the art of building. What is presented in the 'vibration of lines' against the blank walls of these shops is an image of pure potentiality.

The image of the tabula rasa in relation to modernism has more recently come to be understood as a form of erasure and repression, rather than of receptivity, with the potentiality of blankness itself erased. ${ }^{9}$ But the metaphor of the tabula rasa, the writing tablet on which nothing exists, had previously expressed the existence of a genuine potentiality. Agamben notes "all potential to be or do something is ... always also potential not to be or not to do"; otherwise potentiality would always already have passed

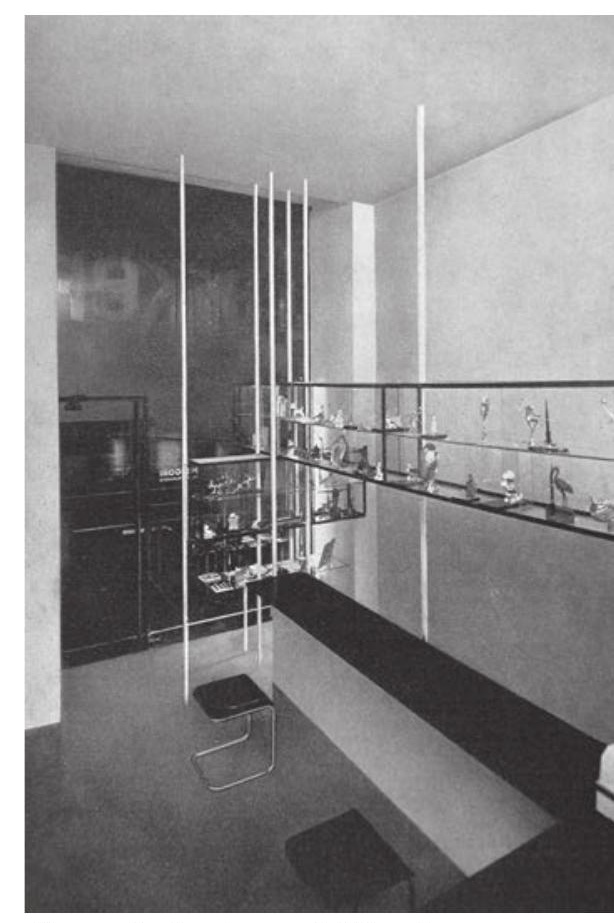

Figure 2: Persico and Nizzoli, Parker Shop in Largo Santa Margherita, Milan 1934.

8. The first was demolished in 1964, the second bombed in 1943.

9. The image derives ultimately from that of the nous, thought or mind, in Aristotle's De Anima $(430$ a 1$)$ where the mind "has no other nature other than being potential, and before thinking it is absolutely nothing". Thus, he writes, "the nous is like a writing tablet on which nothing is actually written". 
10. For a resonance with Boccioni, cf. note 4 . The potential of the blank surface plane had, of course, already become apparent in Suprematism and the anti-perspectival space of parallel projection, when, in El Lissitzky's words, Suprematism "shifted the vertex of the optical pyramid to infinity" (1925: 107). Before him, Malevich had written in 1919: "I have ripped through the blue lampshade of colour. I have come out into the white. Follow me, comrade aviators, sail on into the depths-I have established the semaphores of Suprematism." (1969: 122) Malevich's white abyss/ plenitude plays with the perceptual possibilities of black and white, negating them, to create an optically ambivalent space where their rhythmic interplay suggests an infinite world of copossibilities.

II. Both Suprematism and Neoplasticism were derived from the right angle and emphasised directionless space. The vertical axis determining the familiar horizontal view "from which man looked about the earth" was changed when the aeroplane, opening a new sphere of spatial experience, as Benjamin stated, "broke the monopoly of the vertical” (Benjamin, 1972: 538). See also Asendorf (1997). 12. In this era, a line or mark, or word on paper, came to be conceived no longer as contained on a surface but related to a ground of indefinite depth. So, in the Parker shops, nothing quite touches the walls; and yet, seemingly indefinite, the thin steel sections pass through the walls, ceiling, and floor, running off the edge of the paper. into actuality and would be indistinguishable from it (1999: 215). The blank tablet is an image of the pure potentiality of thought itself. The mind is not an intelligible object; it has no other nature than that of being potential. Before thinking it is nothing. But, comments Agamben, it "allows for the act of thinking to happen, just as the film of impressionable wax is suddenly grazed by the scribe's stylus" (245). Because potential to be or to do is also potential not to be or do, "thought exists as a potential to think and not to think as a wax writing tablet on which nothing is written ..." (245). In this sense, blankness in Persico's shops is the space where quivering lines trace thought and unexhausted potentiality. ${ }^{10}$ The works keep open the possibility of non-actualisation, of not fully being.

The notion that a drawing or model of something unrealised is itself a form of potential architecture is not unfamiliar. Here, the contrasts between black and white, vertical and horizontal, so fundamental to Suprematism and Neo-plasticism, ${ }^{11}$ take on a graphic note that Giulia Veronesi's caption to the first Parker shop did not fail to detect:

a weave of infinite lines traced by thin straight poles in square section, black and white extended the exquisitely graphic structure of the elevation into the dynamic of the third dimension, creating volumes of transparency alone, perspectives lyrically excited by varying the viewpoint and by the very nature of the materials, but rigorously 'held' ... (Veronesi in Persico, 1964: s.p.)

In both shops, in fact, it is as if the space had supremely attained the third dimension but, at the same time, had preserved something of the two dimensions of graphics. It is not just because it is difficult physically to locate a thin line before the eyes in space, nor because the fittings are for the most part in a-tectonic suspension, nor even because they refer to the weightless co-ordinates of Suprematism and Neo-Plasticism. The lightness hints at something unactualised, the pure capacity of architecture to become a matter only of a vibration of lines against blankness. ${ }^{12}$ The perceptual play between black and white, their rhythmic interplay suggesting co-possibilities, is paralleled by that between the optically vibrating lines and their background. Veronesi wrote, "Nothing other than moments of pure rhythm was intended in the infinite of a Metaphysical atmosphere created by diffuse white light" (in Persico, 1964: s.p.).

The mountings and cases compose an architecture of 'construction lines', the scaffolding of an image-austerely intellectual like early Renaissance wire-frame perspectives, but without the intention to define a threedimensional object. The presentation of "only a vibration of lines", the "volumes of transparency alone" (Giolli, 1937: 30); the wavering of asymmetric balance; the flickering between three dimensions and layers on paper; the refusal to come to ground (as the elements graphically hover in "moments of pure rhythm" between black and white, between line and blank ground; Veronesi in Persico, 1964: s.p.) ... all intimate a suspension that conserves and exercises in the realised work a potential not actualised. Between the presentation of nothing, in blankness, and the presentation of something, in lines, lies the event of materialisation-manifest as typos, as trace. Persico maintains a reserve in the finished work that, keeping actuality in suspension, reveals the traces of a process of thought. ${ }^{13}$ 
In the Parker shops, design begins with and returns to the graphic, to the black of ink and the white of paper-the possibilities in graphic space. They exhibit the space of communication as an experience of possibility. The black does not touch the white but is held back from it as if in an act of creation according to the model of thought thinking itself. "In the Arab tradition", Agamben notes, "agent intellect has the form of an angel whose name is 'Pen' (Qualam), and its place is unfathomable potentiality" (Agamben, 2003: 36-7) ${ }^{14}$ Tectonic suspension is joined here by a sceptical suspension. They mark the point at which architecture retreats from rhetoric to a silence of pure potentiality, capable of expression precisely by virtue of saying nothing. What matters is not so much speaking or functioning but a return to the grounds on which anything may be communicated: that there exists a medium in which communication takes place, and that what is communicated in this medium is not one thing or another but, first of all, communicability. Suspension is a breath-taking path to virtual non-existence, indetermination, potentiality.

The achievements of the first Parker shop were developed further in June 1934 in the Sala delle Medaglie d'Oro, widely regarded as the foremost exhibit at the Milan Exhibition of Aviation and celebrated as Persico's finest architectural work. The hall commemorated the exploits of Italian aviators in the First World War who received the prestigious Gold Medal. Concealed light was diffused over the white walls by a luminous strip running right around them and evoking sky in the glowing shadowless space between two planes of darkness. The void of the sky and the void of the ground become the same. An explosion of documents remains suspended between them and at the threshold between oblivion and consciousness. Photographic panels, artefacts, and texts are mounted on a series of slender white scaffolds. Above head-height, a single continuous frame runs lengthwise through the hall, like a fuselage in translucent scrim. Carrying the floating relics of heroic aviators, they evoke loss, flight, and the suspension of time. The frames offer an idealized realisation of the grid as pure abstraction that, nevertheless, elides with a recurring figurative element: the box frame structure of the first bi-planes. As in Futurism, there is no return to earth. However, flight is here not represented as willed ascent and mastery but as suspension, loss of ground, force spent, diffused and vanished.

Similarly, in Persico's last project of 1936, the Salone d'Onore at the Milan Triennale, narrow white walls played a rapid and urgent beat, suggesting ascents and "improbable climbs" (Giolli, 1936: 19). And again, the image of feathers and wings appears in Giolli's description: the thin pilasters of the exhibition are "like a fluttering of wings" and seem to "detach themselves from the wall to vibrate alone" - the effect is dizziness. A precisely determined installation, it nevertheless had the capacity of producing the perception of something indeterminate, something out of grasp. Potentiality is, after all, "not simply non-Being, simple privation, but rather the existence of non-Being, the presence of an absence" (Agamben, 1999: 179).

\section{Irony: Suspension of Self}

In both Persico and Albini's work the doubt and instability a displacement into the air can produce found an expression in irony. Albini, in particular, explored notions of risk and balance. Purely tectonic suspension
13. The very idea of space, as something that can never be fully realised, is a form of potentiality. Only because architecture is capable of building nothing, that is, the non-material which is space, can it build anything; otherwise, it remains only an art of the imposing mass, shelter, functioning mechanism, or advertisement. What is frequently termed modernist 'dematerialisation' must, rather, be understood as materialisation. Beyond reduction to purpose lies a potentiality not exhausted in the passage to actuality.

14. In the second Parker shop, the figure of an angel even materialises. After the exorcism of all figuration, the messenger appears, solidly actualised in this graphic space as a prop or support to its suspended abstraction. The pinioned aggelos bearing pens is a redundant and ironic doubling: the medium of communication bearing the medium of communication. And the angelic announcement/creation is, anyway, already there as the space itself, in black and white. The low little angel signifies a fall; it brings us down to earth. 


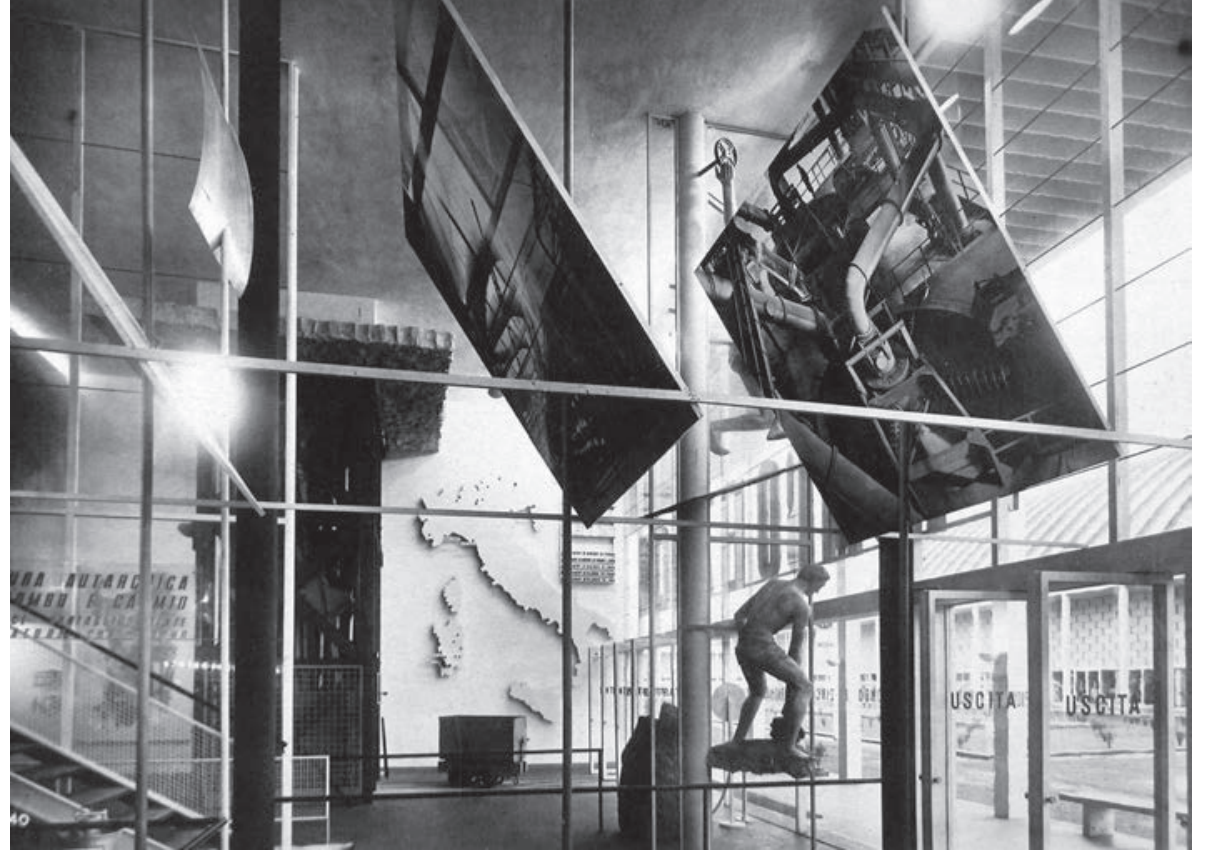

Figure 3: Albini, Lead and Zinc Pavilion for Montecatini, Rome 1938.

is in his work often accompanied by hints of the acrobatic: for example, the Sailing Ship bookcase (1938-40); the project for the Bombini-Parodi-Delfino Stand at the Milan Trade Fair (1947), structured as a highly improbable series of scales balanced from scales; or the extraordinary stand for the sculptural group of Marguerita of Brabant in the Palazzo Bianco (1945-51). All allude to the element of grace as the acceptance, but deflection, of the weight of necessity and the element of irony.

Despite the fact that gravity, as Jankélévitch observes, "in the double meaning of serious and geotropism, is ... our natural tendency" (1964: 31), consciousness can detach itself from life and things. As epoche, this does not simply lead to indifference but to an experience of possibility (20). "Irony", Jankélévitch notes, "is the disaggregation of every 'res' or dereification" (183). In posing questions, thought chops up the apparent solidity of what is taken for granted, making fissures. Thus, it is able to suspend the self, "able to look left and right and strip off at last the heavy mantle of necessity" (22).

In his Room for a Man, the task was to give form to rationality, specifically to exhibit the rationality of standardisation. Albini represented this by the abstraction of a three dimensional grid. But housing even the barest essentials unavoidably leads to a situation where material things, such as coats, undercut the abstraction as a reminder of man's bodily relationship to the world. Similarly, the universal aspirations of the grid are undercut by the singular fantasy of the bed (reached, acrobatically, via ladder and the top of the bookcase). The ironic note in Albini's work does not come as a sudden addition, but is present from his earliest projects-an ashtray that intimates a propeller fan and a floating hammock for an aviator.

The Lead and Zinc Pavilion for Montecatini, at the exhibition Autarchy of the Italian Mineral (Rome 1938), was planned as a display of the phases of national production: from the excavation of the raw minerals from the bowels of the earth, through their extraction and processing, to their use as products. The exhibition's itinerary proceeded from an 'underground' area, representing a mine with mineral deposits, up a ramp that continued on as a raised gallery in a double-height space from which the heavy machinery exhibited below could be viewed. The narrative was thus developed from subterranean confinement, through various transformations, to an aerial release in the form of sheets of metal hoisted like sails. Throughout the exhibition, thread-like uprights and horizontals contrasted with sachlich elements such as the raw materials, rocks, ores, alloys, and the machinery used to wrest them from the earth in mining and metallurgy. A rough- 
hewn slab overhung the entrance to threaten the arriving visitors, who were also greeted by realist sculptures of heroic workers suspended in the air. The sail-like sheets exhibited as the end product of the process were skewered on the uprights like the accompanying photographic placards of machinery, which tilted menacingly overhead, confronting the visitor descending the stair to exit. This not only added a touch that perhaps reflected the boring and drilling required in excavation, but also Albini's views on the politics of autarchy as excavation of the home ground. Irony here is the expression of a split between one part of the designer that exists in a state or situation of inauthenticity, and another part that exists only in the form of questioning, and that asserts the knowledge of this inauthenticity.

Twenty-three years later, at the height of Italy's economic miracle, the exhibition Organisation, Productivity, Market at the International Exposition of Labour (part of Italia '61) provided another opportunity for a comment on the state of technology. Panels illustrating the evolution of machines and industrial production circulated on industrial conveyor systems, rising and descending like materials of assembly in a factory ("Italia '61: La Ricerca Scientifica, L'organizazzione Industriale, La Produttività, Il Mercato," 1961: 241).

Necessity, embodied in functionalist theory or the assembly line, may appear to offer little chance for humour, but "the comic is an effect of contingency: monkeys make us laugh because they could be men". Therefore, "what is funny, according to Bergson, is not the mechanism, as such, nor the vital as such, but the automatic, that is to say, the machine that breathes, or the man who looks like a machine" (Jankélévitch, 1964:155). So, when images circulate like mechanised sandwich-board men bearing allusions to the cycle of serial production and its inevitable discarded leftovers, reality becomes too light. ${ }^{15}$ When knowledge of inauthenticity combines with an inability to overcome it, irony gains momentum. When the assembly line doubles as a tool for exhibiting and an object-symbol of the industrial cycle exhibited, reality becomes a disposable image of itself. In a reflective
15. Tentori notes that the panels, "far from being only neutral supports of the didactic history-metamorphose, in my imagination, into a slow Indian file of sandwich men, as in photos of a marching protest in an American strike of the '30s" (1965: ).

Figure 4: Albini and Helg, International Work Exhibition, Italia '6I.

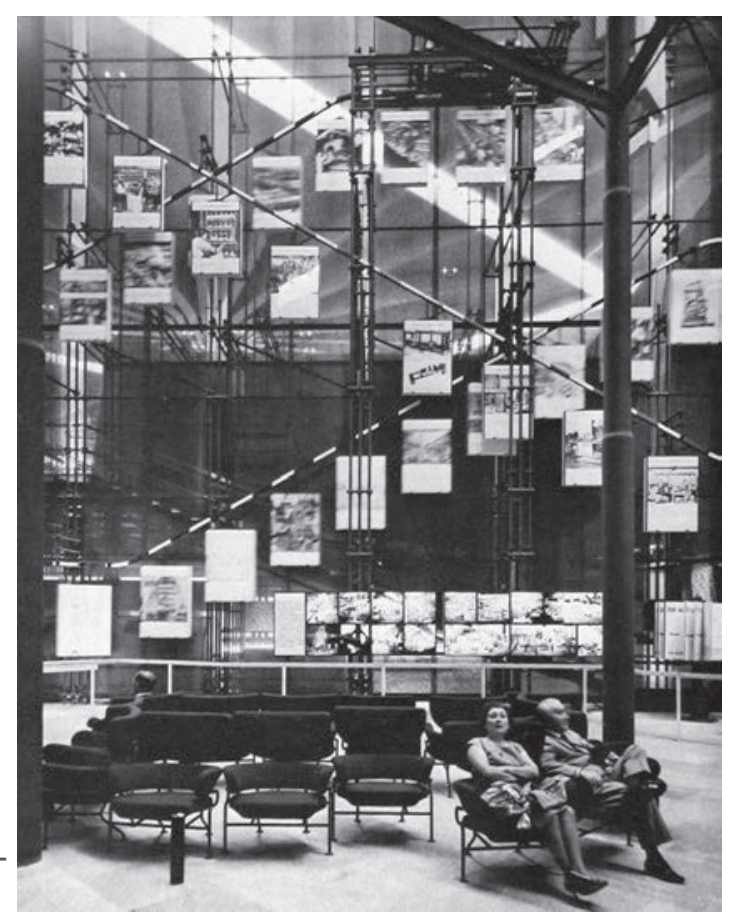




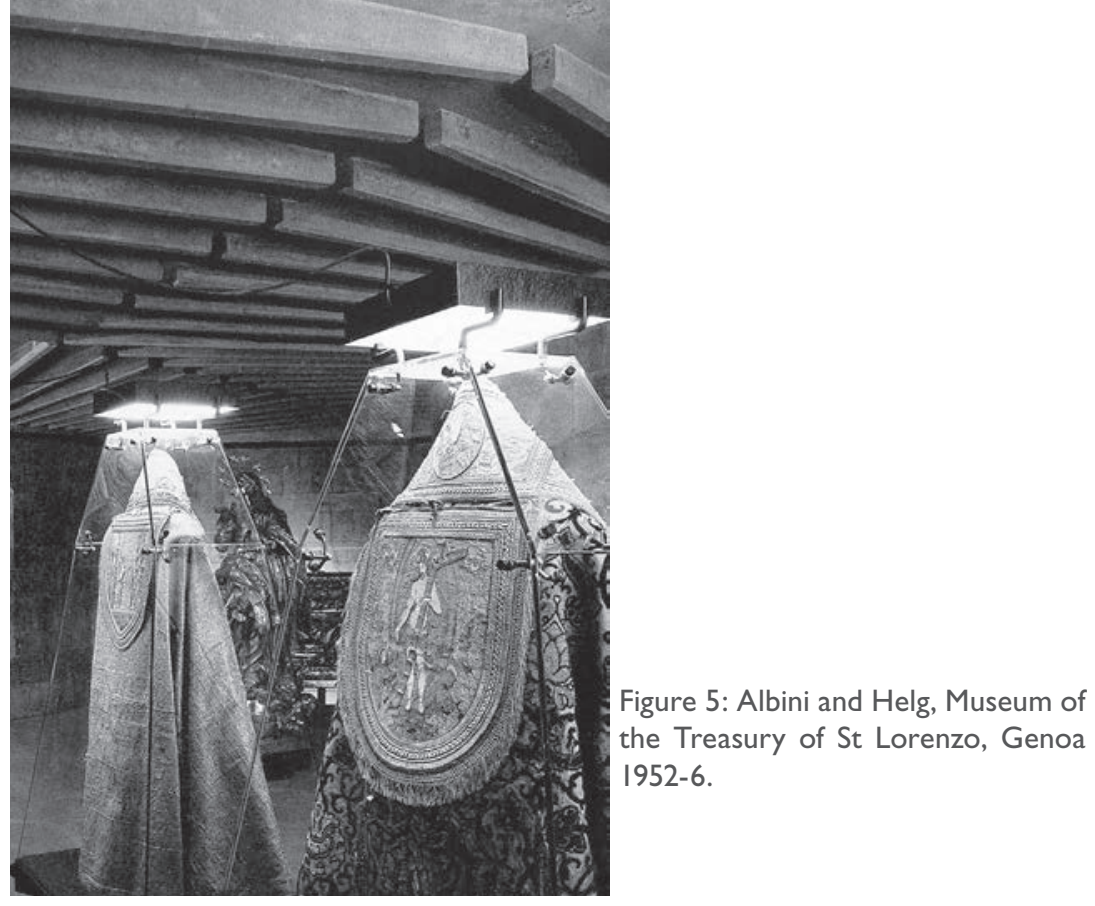

16. And this is perhaps the moment where, in Schopenhauer's observation (1958: 405), grace is the denial of will. disjuncture, the meaning of mechanical reproduction is made evident, and the viewers watch it circulating like skiers on a chairlift from below in the comfort of armchairs. Representation thus affords the disaggregation necessary to strip off the heavy mantle of necessity and the possibility to think and laugh.

Gravity is at the core of this play of forces, and the fact that objects are, of necessity, physically hung or propped to counter their weight creates in his works at times an incongruency Albini seems to have deliberately set in scene. What goes up, must come down ... But, must it? There is a long, drawn-out moment of hesitation in his suspension. ${ }^{16}$ The difference between Nietzsche's eternally falling stone and the bucket knight is that one achieves freedom by accepting necessity, whereas the other drifts away never to return. While Albini's designs have the lightness of the one-off and the exhibition, the ephemerality of the bucket knight, they also have an acceptance of the necessities of programme and tectonics (Nietzsche's stone). Grace, the show of good will, will later lead Albini to moments of serenity and a curious weightlessness when, without force or anxiety, he accepts the pull of multiple gravities operating in the Treasury of San Lorenzo, both of the suspended objects and that of the building floating in the ground.

The heavy necessities imposed by instrumental rationality seem, paradoxically, to have brought about a lightness in the work of Persico and Albini that unpredictably surpassed necessity in meeting and fulfilling it. Modes of design thinking arose that did not leap instantly to a vertical transcendence but tended to defer and withhold it. Spreading out horizontally, they achieved a tectonic suspense, returning lightness to the everyday and to the materiality of air itself.

\section{References}

Agamben, G. (1986). Quattro glosse a Kafka. Rivista di estetica (22, anno 26), 37-44.

Agamben, G. (1999). Potentialities: Collected essays in philosophy. Stanford, CA: Stanford University Press.

Agamben, G. (2003). The coming community. Minneapolis: University of Minnesota Press.

Asendorf, C. (1997). Super constellation. Flugzeug und Raumrevolution. Vienna: Springer Verlag.

Benjamin, W. (1972). Gesammelte Schriften (Vol. 3). Frankfurt a. M.: Suhrkamp.

Boatto, A. (1992). Della guerra e dell'aria. Genua: Costa e Nolan.

Boccioni, U. (1971). Gli scritti editi e inediti (Zeno Birolli, Ed.). Milan: Feltrinelli. 
Boccioni, U. (1977). Pittura scultura futuriste: Dinamismo plastico. Florence, Vallecchi.

Boccioni, U. (1997). Architettura futurista: Manifesto. In E. Godoli (Ed.), Il Futurismo (3rd ed., 185-187). Rome-Bari: Laterza.

Calvino, I. (1988). Lezioni americane. Sei proposte per il prossimo millennio. Milan: Garzanti.

Calvino, I. (1996). Six memos for the next millenium. London: Vintage.

Fermi, L. (1961). Mussolini. Chicago: University of Chicago Press.

Fossati, P. (1971). L'immagine sospesa. Pittura e scultura astratta in Italia, 1934-40. Turin: Einaudi.

Frascari, M. (2000). A Light, Six-Sided, Paradoxical Fight. Nexus Network Journal, 4 (2 Spring http://www.nexusjournal.com/Frascari_v4n2.html).

Giolli, R. (1936). VI Triennale di Milano: ‘La Sala della Vittoria'. Casabella (102-103 JuneJuly), 14-21.

Giolli, R. (1937). Negozi a Milano. Casabella (109, January), 30-31.

Gregotti, V. (1988). Six memos per l'architettura. Casabella (October), 2-3.

Ingold, F.P. (1978). Literatur und Aviatik: europäische Flugdichtung 1909-1927. Mit einem Exkurs über die Flugidee in der modernen Malerei und Architektur. Basel: Birkhäuser.

Italia '61: La Ricerca Scientifica, L'organizazzione Industriale, La Produttività, Il Mercato. (1961). L'architettura. Cronache e storia (70 August).

Jankélévitch, V. (1964). L'Ironie. Paris: Flammarion.

Lebel, R. (1959). Marcel Duchamp. New York: Paragraphic Books.

Lissitzky, E. (1925). K. und Pangeometry. In Europa Almanach (103-113). Potsdam.

Lynn, G. (1994). Differential gravities. Architecture New York (March/April), 20-23.

Malevich, K.S. (1969). Essays on art, 1915-1935 (X. G.-P. \& A. McMillin, Trans.). London: Rapp \& Whiting.

Manifesti del futurismo lanciati da Marinetti Boccioni. (1914). Firenze: Lacerba.

Marinetti, F.T. (1909/1968). Manifeste initial du Futurisme. In Teoria E Invenzione Futurista. Milan: Arnoldo Mondadori.

Nietzsche, F. (1961). Thus spoke Zarathustra (R.J. Hollingdale, Trans.). Harmondsworth: Penguin.

Persico, E. (1964). Edoardo Persico Tutte le Opere. Milan: Edizioni di Communità.

Prampolini, E. (1984). L’Atmosferastruttura. In E. Crispolti (Ed.), Architettura Futurista (pp. 88). Modena: Fonte D'Abisso.

Rajchman, J. (1994a). Constructions. Cambridge, Mass.: MIT Press.

Rajchman, J. (1994b). The Earth is Called Light. Architecture New York, 1, N.5 (March/April), 12-13.

Rajchman, J. (1994c). Lightness: A concept in architecture. Architecture New York, 1, N.5 (March/April), 5-7.

Schopenhauer, A. (1958). The world as will and representation (Vols. 1 \& 2). New York: Dover.

Tentori, F. (1965). Opere ricenti dello studio Albini-Helg. Zodiac (14), 94-127.

Vogt, A.M. (1989). Das Schwebe-Syndrom in der Architektur der zwanziger Jahre. In Das architektonische Urteil. Annäherungen und Interpretationen von Architektur und Kunst (201-233). Basel: Birkhäuser.

Wohl, R. (1994). A passion for wings: Aviation and the Western imagination 1908-1918. London and New Haven: Yale University Press.

Wölfflin, H. (1994). Prolegomena to a Psychology of Architecture. In H.F. Mulgrave (Ed.), Empathy, form, and space: Problems in German aesthetics 1873-1893 (149-190). Santa Moni ca, CA: The Getty Centre for the History of Art and Humanities. 